\title{
Antibacterial Properties of Polyurethane / Benzalkonium Chloride Nanofibers
}

\author{
Poliüretan/ Benzalkonyum Klorür Nanoliflerin Antibakteriyel Özellikleri
}

\author{
Ayşe Feyza ARSLAN ${ }^{1}$ (D), Metin YÜKSEK ${ }^{2}$ (D) ${\text { Erdem } \text { TEZCAN }^{3} \text { (D), Erkan İ̧̧GÖREN }}^{4}$ (D), \\ Derya SALTIK ${ }^{1}$ (D), Mehmet AKALIN ${ }^{1}$ (D), Onur YOLAY ${ }^{5}$ (D) \\ ${ }^{1}$ Institute of Pure and Applied Sciences Textile Engineering, Marmara University, Istanbul, Turkey. \\ ${ }^{2}$ Textile Engineering, Faculty of Technology, Marmara University, Istanbul, Turkey \\ ${ }^{3}$ Department of Biomedical Engineering, Faculty of Engineering, Istanbul Aydin University, Istanbul, Turkey \\ ${ }^{4}$ Textile Education, Faculty of Technical Education, Marmara University, Istanbul, Turkey, \\ ${ }^{5}$ Department of Nutrition and Dietetics, Faculty of Health Sciences, Istanbul Aydin University, Istanbul, Turkey
}

\begin{abstract}
The textile sector brings us different functional features besides our need for dressing. One of them is to give antibacterial properties to textile structures. Antibacterial property increases the quality of life by protecting people against bacterial attacks. It is possible to achieve antibacterial activity at different stages of textile production processes. One of these processes is the electrospinning method, which makes it possible to add antibacterial substances into a polymer containing solution to be processed to a nanofiber structure.

In this study, nanofiber structures were obtained by electrospinning from polyurethane (PU)/benzalkonium chloride (BAC) solutions at different concentrations. Then, their morphological, mechanical and antibacterial characteristics were investigated.

According to the results, the produced fiber membranes had nanometer size. The nanofiber surfaces were intensive and uniform when BAC concentration was $0.5 \%$ and $1.0 \%$. But, the uniformity lost at the higher BAC concentrations. The thinnest fiber diameter of nanofibers was $423 \pm 80 \mathrm{~nm}$. The strongest $(6,42 \mathrm{MPa})$ nanofiber structure was observed when the electrospinning solution included $0.98 \%$ PU and $1 \%$ BAC.

The antibacterial activities of the fabrics were tested against gram-negative (E. coli and P. aeruginosa) and gram-positive (B. subtilis and S. aureus) bacteria. The fabrics showed antibacterial activity with a dose dependent manner against all the tested bacteria by the order of B. subtilis $>$ S. aureus $>$ E. coli $>$ P. aeruginosa.
\end{abstract}

Keywords: Electrospinning, benzalkonium chloride, antibacterial, nanofiber

$\ddot{O} z$

Tekstil sektörü, giyinme ihtiyacımız dışında bizlere farklı fonksiyonel özellikler de getirir. Bunlardan biri de tekstil yapılarına anti bakteriyel özellik kazandırmasıdır. Antibakteriyel özellik, insanları bakteriyel saldırılardan koruyarak yaşam kalitesini arttırması hedefiyle yapılır. Tekstil üretim proseslerinin farklı basamaklarında anibakteriyel özellik kazandırma işlemi gerçekleşebilir. Bunlardan biri de elektroçekim yönteminde antibakteriyel maddelerin lif çekilecek polimere eklenmesiyle yapılmasıdır.

Bu çalışmada, nanofiber yapılar, farklı konsantrasyonlarda ki poliüretan (PU) / benzalkonyum klorür (BAC) çözeltilerinden elektroçekim ile elde edilmiştir. Daha sonra morfolojik, mekanik ve antibakteriyel özellikleri incelenmiştir.

Elde edilen sonuçlara göre, üretilen lif membranları nanometre boyutuna sahiptir. Nanolif yüzeyler, BAC konsantrasyonu \% 0.5 ve $\%$ 1.0 olduğunda yoğun ve homojendir. Ancak, homojenlik yüksek BAC konsantrasyonlarında kaybolmuştur. En kalın nanolif ap1 $423 \pm 80$ nm'dir. En dayanıklı (6,42MPa) nanolif yapısı, elektroçekim çözeltisi \% 0,98 PU ve \% 1 BAC içerdiğinde gözlenmiştir. 
Yüzeylerin antibakteriyel aktiviteleri, gram negatif (E. coli ve P. aeruginosa) ve gram pozitif (B. subtilis ve S. aureus) bakterilere karşı test edilmiştir. Yapılar, test edilen tüm bakterilere karşı doz miktarına bağlı olarak, sırasıyla B. subtilis $>$ S. aureus $>$ E. coli $>$ P. Aeruginosa antibakteriyel aktivite göstermiştir.

Anahtar Kelimeler: Elektroçekim, benzalkonyum klorür, antibakteriyel, nanolif

\section{INTRODUCTION}

Nanotechnology is an emerging interdisciplinary area, with more and more relevance in all fields of science and technology. One of these fields is textile industry. Textiles have been experiencing nanotechnology benefits in a wide range of applications and were considered one of the most promising technological domains [1]. Electrospinning is as a very powerful method for creating and diverse kinds of microstructures [2]. Electrospinning has gained attention recently due to the development of advanced models to increase production rate. Thus, electrospun fibers are used in many applications such as textiles, filters, composites, sensors, tissue engineering, and catalysts [3].

Polyurethane (PU) polymer is a thermoplastic resilient elastomer that have excellent flexibility, good film/fiber forming property and resistance to solvents [4]. Benzalkonium chloride (BAC) belongs to the group of quaternary ammonium compounds, which are commonly used as antimicrobials, disinfectants or surfactants in industrial and household products [5].

Khil et al. used a fiber membrane produced from nanofibers obtained from electrospinning of the polyurethane polymer as a wound healing band. The membrane used as the wound healing dressing was produced at a thickness of 3.25 $\mu \mathrm{m}$ and the water permeability measurement was $6.525 \times 10^{6}$ $\left(\mathrm{cm}^{3} . \mathrm{cm} / \mathrm{cm}^{2}\right.$. s.cm Hg). The obtained PU membrane was found to have effective porosity [6]. Lakshman et al. used a network of polyurethane nanofibers containing silver nanoparticles produced by electrospinning for use in wound dressings. The fiber diameters were between 1.2-1.5 $\mu \mathrm{m}$. Silver nanoparticles increased conductivity and reduced fiber diameter. The conductivity of polyurethane without silver nanoparticles was $1.75 \mu \mathrm{S}$ and addition of silver nanoparticles at different concentrations increased the conductivity to $96 \mu \mathrm{S}$. The fiber diameters are between 150 and $250 \mathrm{~nm}$. The results showed that PU-silver nanofiber felts could be used for wound dressing applications. It can also be used for inhibition of bacterial colonization [7]. Li, Lou and Song studied the tendency of the direction-independent fiber mat produced by polyurethane electrospinning, the stress-strain curves and the maximum loading and breaking behavior. It was seen that the increase of the mat thickness did not affect the maximum strain. However, the maximum load was directly proportional to the mat thickness. At the break point, the maximum tension was inversely proportional to the increase in thickness [8]. Unnithan et al. produced an antibacterial electrospun nanofiber in 400-700 $\mathrm{nm}$ size with polyurethane (PU) and two biopolymers such as cellulose acetate (CA) and zein. To prevent common clinical infections, streptomycin sulfate was added and antimicrobial abilities against gram negative and gram-positive bacterial strains were investigated. These studies showed that these advanced PU-CA-zein-streptomycin sulfate composite nanofibers could be used for burn, chronic and diabetic wound infections [9]. Toncheva and friends researched that Poly (L-lactide) (PLLA) and PLLA / poly (ethylene glycol) (PEG) polymers were prepared by electrospinning method with diclofenac sodium (DS), lidocaine hydrochloride (LHC), benzalkonium chloride (BAC), and their combinations. The PLLA/PEG containing BC (10 wt $\%)$, DS (30 wt $\%)$, DS/LHC (DS,30 wt $\%$; LHC, $30 \mathrm{wt} \%$ ), and DS/LHC/BC (DS, $15 \mathrm{wt} \%$; LHC, 15 $\mathrm{wt} \%$; and $\mathrm{BC}, 10 \mathrm{wt} \%$ ) exhibited antibacterial activity against the pathogenic S. aureus bacteria [10].

The aim of this study is investigation of morphological, mechanical and antibacterial properties of fibers produced with electrospinning of polyurethane and benzalkonium chloride solutions in THF/DMF $(50 / 50, \mathrm{w} / \mathrm{w})$.

\section{MATERIALS AND METHODS}

\subsection{Materials}

Polyurethane (PU) block co-polymer pellets (consists of difhenylmethane-4,4'-diisocyanate, adipic acid, ethylene glycol, ethylene oxide, polypropylene oxide, 1,4-butanediol and bisphenol A) were purchased from SMP Tecnologies Inc. (Japan). Dimethyl formamide (DMF) and tetrahydrofuran (THF) were selected to dissolve the polyurethane. Alkyldimethylbenzylammonium chloride (benzalkonium chloride) $(50 \%)$ was of analytical grade (Kimetsan) and used as received.

Main cultures of Escherichia coli ATCC 35218, Bacillus subtilis ATCC 6633, Staphylococcus aureus ATCC 25293 and Pseudomonas aeruginosa ATCC 27853 were supplied from Microbiologics.

Nutrient broth and nutrient agar (for E. coli and B. subtilis strains) and Trypticase Soy Broth and Trypticase Soy Agar (used for $S$. aureus and P. aeruginosa strains) culture media were supplied from Hi-media. 


\subsection{Methods}

\subsubsection{Preparation of polymer solution}

$10 \%$ polyurethane $(\mathrm{PU})$ stock solution was prepared by dissolving $1 \mathrm{~g}$ PU in $9 \mathrm{~g}$ DMF/THF $(50 / 50, \mathrm{w} / \mathrm{w})$ for three hours. Then, according to Table 1, several amounts of the stock PU solution and $50 \%$ BAC solution was mixed, and the total mass was adjusted to $10 \mathrm{~g}$ using 50/50\% DMF/THF mixture. The solution was stirred for 1 hour before electrospinning. The ingredients and the final concentrations of the sample solutions to be electrospun were listed in Table 1 .

Table 1: The final concentrations of the sample solutions for electrospinning. The concentrations were adjusted to $100 \%$ with DMF/THF $(50 / 50, \mathrm{w} / \mathrm{w})$ mixture

\begin{tabular}{|l|l|l|}
\hline Sample Codes & PU (\%) & BAC (\%) \\
\hline $\mathbf{1}$ & 0.99 & 0.5 \\
\hline $\mathbf{2}$ & 0.98 & 1.0 \\
\hline $\mathbf{3}$ & 0.95 & 2.5 \\
\hline $\mathbf{4}$ & 0.93 & 3.5 \\
\hline $\mathbf{5}$ & 0.91 & 4.5 \\
\hline
\end{tabular}

\subsubsection{Nanofiber production by electrospinning method}

The electrospinning device (Inovenso, NE300 Nanospinner) was used to produce nanofibers.

The solutions of $\mathrm{PU}$ alone or $\mathrm{BAC}+\mathrm{PU}$ were put in syringes. Greaseproof paper was placed on the collecting plate to feed the nanofibers to this surface. The optimal parameters were $2 \mathrm{ml} / \mathrm{h}$ feeding rate, $27.5 \mathrm{~cm}$ tip to collector distance, $25 \mathrm{kV}$ applied voltage, $100 \mathrm{rpm}$ collector speed for 2 hours of application time. Experiments were carried out at varying temperatures ranging from 21 to $24^{\circ} \mathrm{C}$. The same machine parameters have been applied to all samples.

\subsubsection{The viscosity and conductivity of solutions}

The viscosity of the polymer solutions was determined by using viscometer (Brookfield DV-E Viscometer, USA). The viscosity measurement was performed with $\mathrm{S} 21$ spindle at $100 \mathrm{rpm}$. The conductivity values of the polymer solutions were measured by conductivity meter (WTW Cond 3110, Germany). All the viscosity and conductivity experiments were carried out at room temperature.

\subsubsection{Morphology of nanofiber structure}

The morphologies of the electrospun nanofibers were analyzed with SEM images (JEOL JSM-5910 LV, Japan). The average fiber diameter of the PU/BAC nanofibers was measured by Image $\mathrm{J}$ software from the SEM images.

\subsubsection{Mechanical tests}

The mechanical properties are very important with regard to the performance of the samples. The thicknesses of the samples were measured in the horizontal and vertical directions by Mitutoyo Digital Thickness Comparator. The samples were tested by Instron 4411 Universal Test device in size of 50x10 mm (length x width).

\subsubsection{Determination of antibacterial activity}

ISO 20645:2004 method was mimicked to determine the antibacterial activity of wool samples [11]. The bacterial strains stored at $80^{\circ} \mathrm{C}$ were precultured in $10 \mathrm{ml}$ broth medium in shaking incubator at $37 \pm 1{ }^{\circ} \mathrm{C}$ for $16 \mathrm{~h}$. The broth media were Nutrient Broth for E. coli and B. subtilis strains, Trypticase Soy Broth for $S$. aureus and P. aeruginosa. $10 \mu$ of the precultures were inoculated into the desired volume of fresh broth media. Approximate CFU numbers were estimated from McFarland densitometer measurement and the bacterial culture was produced by incubating at $37 \pm 1^{\circ} \mathrm{C}$ until the bacteria concentration reached $10^{8} \mathrm{CFU} / \mathrm{ml}$ [12].

In order to test antibacterial activities of the samples, two-layered soft agar plates were prepared. The soft agar media were formulated by adding $7.5 \mathrm{~g} / \mathrm{L}$ Agar into the broth media described above. The lower layer was $10 \mathrm{ml}$ and did not contain any bacteria. The upper layer was $5 \mathrm{ml}$ and contained $100 \mathrm{ml}$ of the bacterial culture.

Later, each wool sample to be tested in $20 \mathrm{~mm} \times 20 \mathrm{~mm}$ size was placed on the soft agar medium and the petri dishes were incubated at $37 \pm 1^{\circ} \mathrm{C}$ for 24 hours. For accuracy, the experiments were performed and repeated three times. The average diameter of the inhibition zones was calculated using Equation (1) [13]:

$$
\mathrm{A}=(\mathrm{B}-\mathrm{C}) / 2
$$

Where, $\mathrm{A}$ is the average diameter of clear inhibition zone in $\mathrm{mm}, \mathrm{B}$ is the total diameter of inhibition zone including wool sample and clear zone in $\mathrm{mm}$, and $\mathrm{C}$ is the length of the wool sample to be tested.

For comparison, $10 \mathrm{ml}$ of gentamycin stock solution was dropped on bacteria containing separate soft agar medium and diameter of the inhibition zone was measured after incubating at $37 \pm 1^{\circ} \mathrm{C}$ for 24 hours.

\section{RESULTS}

\subsection{Viscosity and Conductivity}

The viscosity and conductivity values of all solutions were measured (Table 2). 
Table 2: The viscosity and conductivity of solutions

\begin{tabular}{|l|l|l|}
\hline Sample codes & $\begin{array}{l}\text { Conductivity } \\
(\mu \mathrm{S} / \mathrm{cm})\end{array}$ & $\begin{array}{l}\text { Viscosity } \\
(\mathbf{c P}-\mathbf{\%})\end{array}$ \\
\hline $\mathbf{1}$ & 223 & $170 \mathrm{cP} \% 34$ \\
\hline $\mathbf{2}$ & 365 & $171 \mathrm{cP} \% 34.2$ \\
\hline $\mathbf{3}$ & 844 & $176 \mathrm{cP} \% 35.5$ \\
\hline $\mathbf{4}$ & 1222 & $134 \mathrm{cP} \% 21$ \\
\hline $\mathbf{5}$ & 1377 & $155.5 \mathrm{cP} \% 31.1$ \\
\hline
\end{tabular}

It was observed that the presence of benzalkonium chloride $(\mathrm{BAC})$ in the solutions increases the conductivity. The viscosity values of solution started to increase in parallel to the first three BAC concentration. After this point, increase of BAC concentration fluctuated the viscosity. The highest viscosity was observed when the samples were electrospun from 2.5\% BAC containing solution (Sample 3).

\subsection{Morphology of the Samples}

The morphologies of the electrospun nanofibers were analyzed with SEM images (Figure 1).
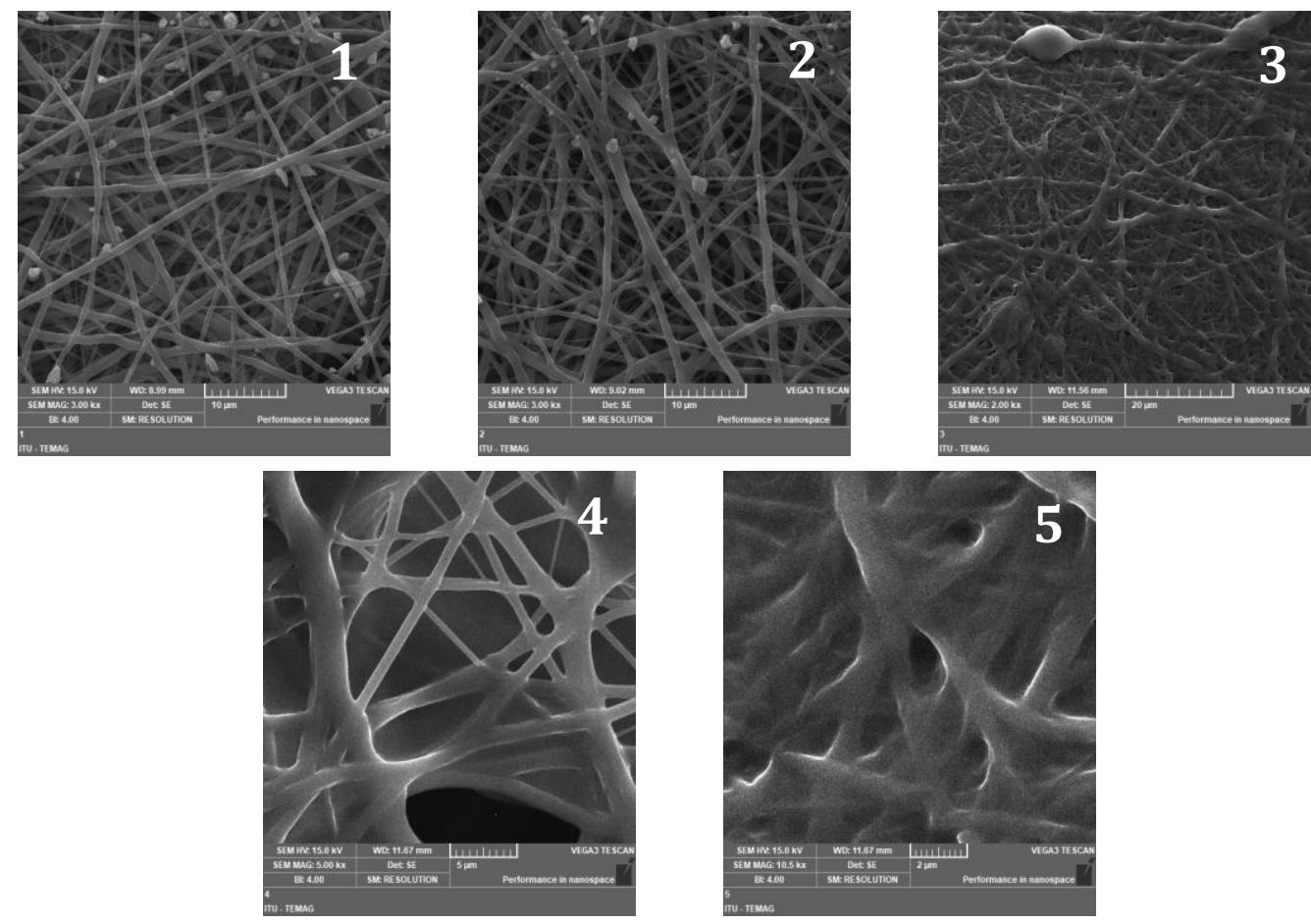

Figure 1: The SEM images of Samples 1-5.

When BAC concentration was $0.5 \%$, the average diameter was $423 \pm 80 \mathrm{~nm}$ (Sample 1). The average diameter was similar $(427 \pm 35 \mathrm{~nm})$ when the BAC concentration was increased to $1.0 \%$ (Sample 2). The nanofiber surfaces of these (Sample 1 and 2) samples were intensive and uniform. However, further increase of BAC concentration prevented nanofiber formation. Therefore, the diameter of the samples 3-5 were not measured.

\subsection{Mechanical Tests}

Vertical and horizontal strength values of PU/BAC nanofiber membranes were measured (Figure 2 and Figure 3).

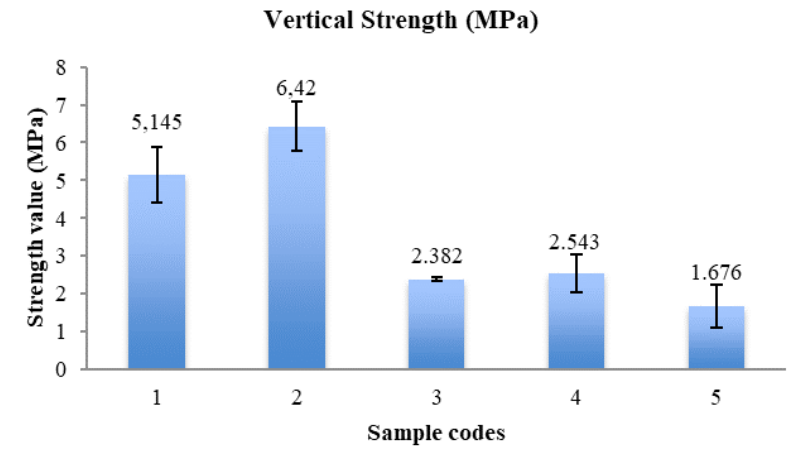

Figure 2: The measured vertical strength values of nanofiber membranes 


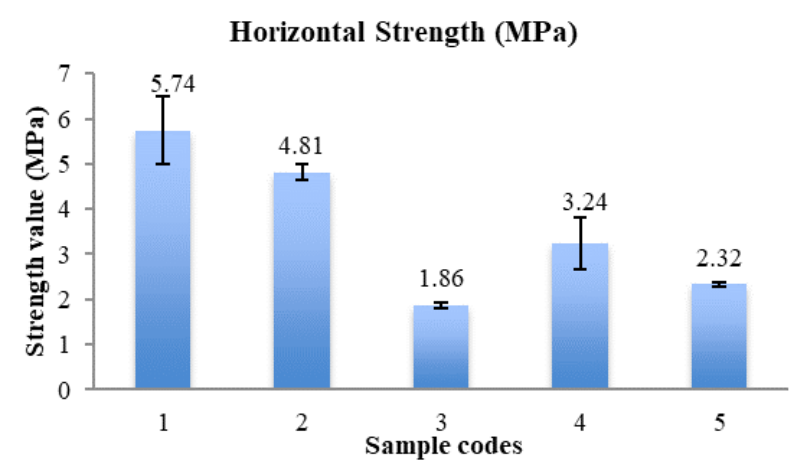

Figure 3: The measured horizontal strength values of nanofiber membranes

The highest vertical strength and horizontal strengths were observed at the lowest BAC concentrations $(0.5 \%$ at Sample 1 and $1.0 \%$ at Sample 2). Increase in BAC concentration $(2.5 \%-4.5 \%)$ caused a significant decrease in the vertical and horizontal strengths at Sample 3-5, where the nanofiber structure had not been observed at the SEM images. Therefore, $\mathrm{BAC}$ concentration should be $\leq 1 \%$ to protect vertical (Figure 2) and horizontal (Figure 3) strengths and to obtain nanofiber structures (Figure 1).

The thicknesses of the membranes were also measured and were shown at Figure 4.

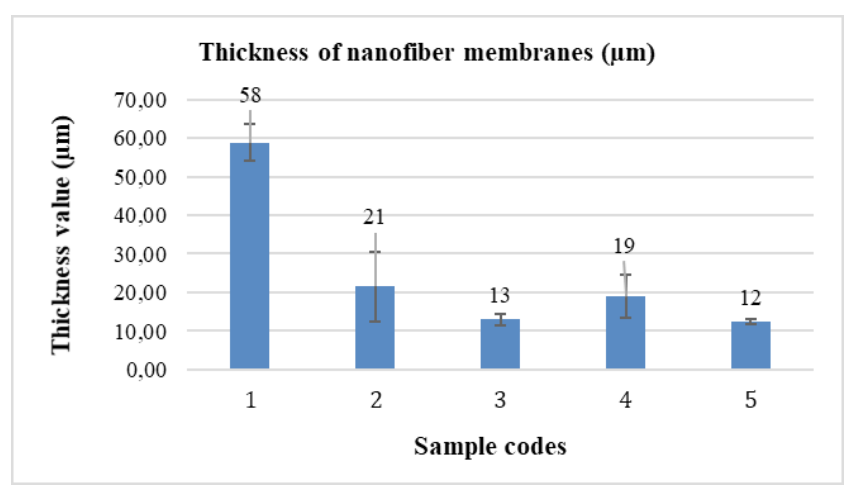

Figure 4: The thickness values of membrane structures
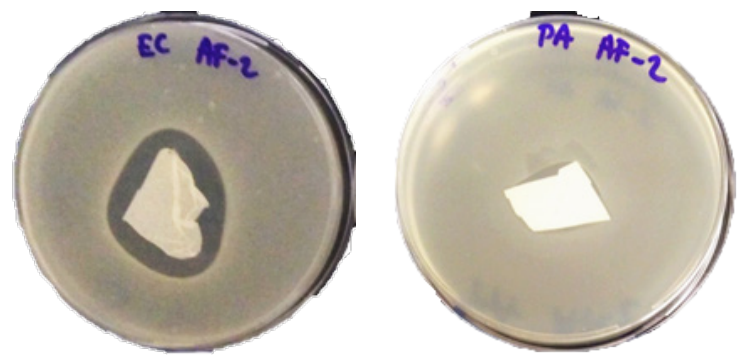

The thickest membrane structure was observed at the lowest BAC concentration $(0.5 \%$ at sample 1$)$. The thickness decreased by increase of BAC concentration. Considering the mechanical properties, the optimal thickness $(0.021 \mathrm{~mm})$ of nanofiber structure was obtained when BAC concentration was $1.0 \%$.

\subsection{Antibacterial Activity}

The antibacterial activities were investigated, and their inhibition zone diameters were measured (Figure 5).

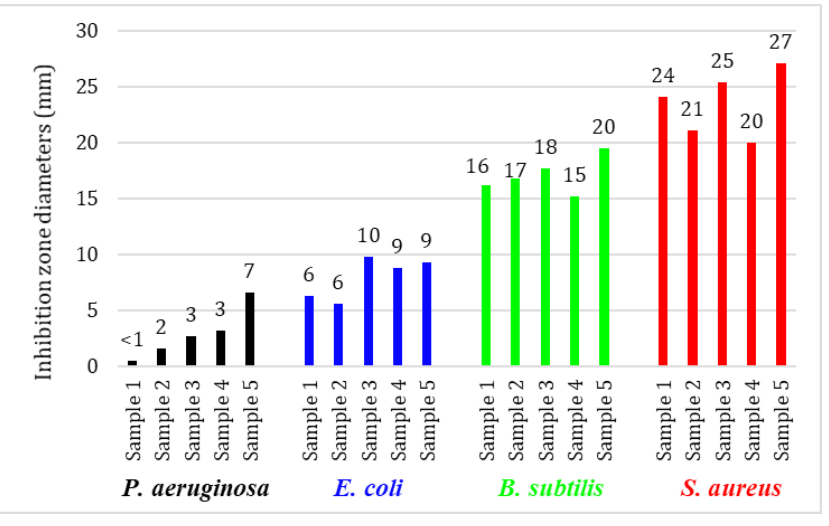

Figure 5: Inhibition zone diameters $(\mathrm{mm})$ created by antibacterial activity of the samples

As shown at Figure 5, all the samples produced inhibition zones against all the tested gram negative and gram-positive bacteria. They were more effective against gram positive bacteria than gram negative bacteria. The inhibition zone diameters were observed in the following order: $P$. aeruginosa $<E$. coli $<$ B. subtilis $<S$. aureus.

The inhibition zones were the smallest against $P$. aeruginosa bacteria and Sample 1 created very low $(<1 \mathrm{~mm})$ inhibition zone. The zone diameters usually increased in parallel to increase in $\mathrm{BAC}$ concentration and the highest zone diameters were observed at the sample produced from the highest BAC concentration (Sample 5). The smallest BAC concentration for reasonable $(>1 \mathrm{~mm})$ antibacterial activity against $P$. aeruginosa was $1.0 \%$, which belongs to Sample 2. Sample 2 created inhibition zone against all the bacteria tested (Figure 6).
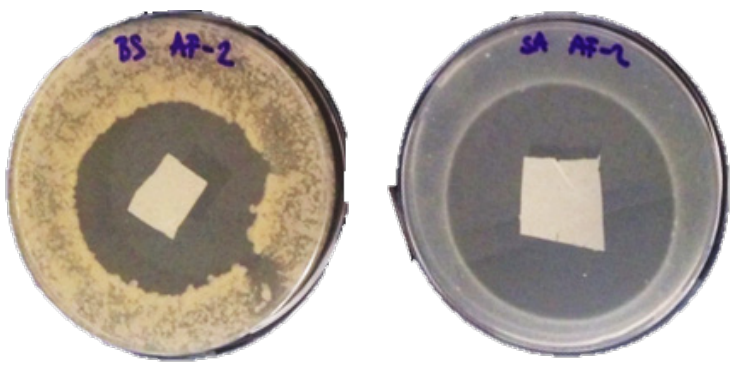

Figure 6: Antibacterial activity of Sample 2 


\section{CONCLUSION}

In this study, nanofiber-based polyurethane was produced by vertical electrospinning method. Several variations were prepared by changing PU $(0.99 \%-0.91 \%)$ and BAC ( $0.5 \%-4.5 \%)$ concentrations and the effect of these variations on morphological, mechanical and antibacterial properties were investigated. It was observed that the presence of $\mathrm{BAC}$ in the solutions increases the conductivity. Uniform and intensive nanofiber membranes were observed with average fiber diameter of $427 \pm 35 \mathrm{~nm}$ at $0.5 \%$ and $1.0 \%$ BAC concentrations (Samples 1 and 2). Further increase of BAC concentration disrupted the uniformity. These two samples, which were electrospun from $0.5 \%$ and $1.0 \%$ BAC containing PU solutions, also had the highest mechanical properties (vertical and horizontal strengths). All the samples caused inhibition zones against gram-negative bacteria (E. coli and P. aeruginosa) and gram-positive bacteria (B. subtilis and S. aureus), but the effect of Sample 1 (electrospun from $0.5 \%$ BAC containing solution) was very low $(<1 \mathrm{~mm})$ against $\mathrm{P}$. aeruginosa, the most resistant bacterium tested. At least $1.0 \%$ BAC concentration needed to have $>1 \mathrm{~mm}$ inhibition zone against $\mathrm{P}$. aeruginosa. The most susceptible bacterium was $S$. aureus and all the samples caused $\geq 20 \mathrm{~mm}$ of inhibition zone against S. aureus. Increase of BAC concentration increased the inhibition zone diameter. By co-evaluating with morphological and mechanical properties, Sample 2 , electrospun from $1.0 \% \mathrm{BAC}+0.98 \%$ PU containing solution, seems optimal for good mechanical and antibacterial properties.

\section{REFERENCES}

[1] Matos, J. C., Avelar, I., Martins, M. B. F., \& Gonçalves, M. C. (2017). Greensilica ${ }^{\circledR}$ vectors for smart textiles. Carbohydrate polymers, $156,268-275$.

[2] Ju, J., Shi, Z., Fan, L., Liang, Y., Kang, W., \& Cheng, B. (2017). Preparation of elastomeric tree-like nanofiber membranes using thermoplastic polyurethane by one-step electrospinning. Materials Letters, 205, 190-193..

[3] Pal, J., Wu, D., Hakkarainen, M., \& Srivastava, R. K. (2017). The viscoelastic interaction between dispersed and continuous phase of PCL/HA-PVA oil-in-water emulsion uncovers the theoretical and experimental basis for fiber formation during emulsion electrospinning. European Polymer Journal, 96, 44-54.
[4] Guyomar, D., Lebrun, L., Putson, C., Cottinet, P. J., Guiffard, B., \& Muensit, S. (2009). Electrostrictive energy conversion in polyurethane nanocomposites. Journal of Applied Physics, 106(1), 014910.

[5] Gaber, M., Shawish, H. M. A., Khedr, A. M., \& Abed-Almonem, K. I. (2012). Determination of benzalkonium chloride preservative in pharmaceutical formulation of eye and ear drops using new potentiometric sensors. Materials Science and Engineering: C, 32(8), 2299-2305.

[6] Khil, M. S., Cha, D. I., Kim, H. Y., Kim, I. S., \& Bhattarai, N. (2003). Electrospun nanofibrous polyurethane membrane as wound dressing. Journal of Biomedical Materials Research Part B: Applied Biomaterials: An Official Journal of The Society for Biomaterials, The Japanese Society for Biomaterials, and The Australian Society for Biomaterials and the Korean Society for Biomaterials, 67(2), 675-679.

[7] Lakshman, L. R., Shalumon, K. T., Nair, S. V., Jayakumar, R., \& Nair, S. V. (2010). Preparation of silver nanoparticles incorporated electrospun polyurethane nano-fibrous mat for wound dressing. Journal of Macromolecular Science, Part A: Pure and Applied Chemistry, 47(10), 1012-1018.

[8] Li X., Lou, W., Song, R., (2009), Experimental Investigation of Polyurethane Electrospun Nanofibers Mat - Relationship Between Mechanical Property and Thickness, IEEE 3rd International Conference on Nano/Molecular Medicine and Engineering, 1-4.

[9] Unnithan, A. R., Gnanasekaran, G., Sathishkumar, Y., Lee, Y. S., \& Kim, C. S. (2014). Electrospun antibacterial polyurethane-cellulose acetate-zein composite mats for wound dressing. Carbohydrate polymers, 102, 884-892..

[10] Toncheva, A., Spasova, M., Paneva, D., Manolova, N., \& Rashkov, I. (2011). Drug-loaded electrospun polylactide bundles. Journal of Bioactive and Compatible Polymers, 26(2), 161-172.

[11] Yurudu, N. S., Erdem, A. K., \& Yürüdü, N. Ş. (2008). The evaluation of antibacterial activity of fabrics impregnated with dimethyltetradecyl (3-(trimethoxysilyl) propyl) ammonium chloride. European Journal of Biology, 67(2), 115-122..

[12] Cheng, C. L., Sun, D. S., Chu, W. C., Tseng, Y. H., Ho, H. C., Wang, J. B., ... \& Yu, M. S. (2009). The effects of the bacterial interaction with visible-light responsive titania photocatalyst on the bactericidal performance. Journal of biomedical science, 16(1), 7.

[13] Yurudu, N. S., Erdem, A. K., \& Yürüdü, N. Ş. (2008). The evaluation of antibacterial activity of fabrics impregnated with dimethyltetradecyl (3-(trimethoxysilyl) propyl) ammonium chloride. European Journal of Biology, 67(2), 115-122. 